REFLECTIONS:

NEUROLOGY AND

THE HUMANITIES

Section Editor

Anne W. McCammon,

MD, FAAN

Adrian Budhram, MD

Correspondence to

Dr. Budhram:

adrian.budhram@medportal.ca

\section{The common stroke}

The common stroke is like a sculpture-

The elbow is crooked, the fingers are curled, The downturned mouth is modelled in clay. At first supple to the guiding hand, the arm Becomes hard, spastic in the kiln of time. Uncommon strokes might be more abstract: A sketched half-portrait, half-neglected blur, Or a stiffly scribbled poem of spoken errors That falters, fumbles, stumbles off the page.

On neurology call, I meet a storm of a man. His visual fields are as full as the midday sun, Glaring down on me until I look away, blinded. His language is turned earth, with vulgar sprouts Drowned by moans of the sick, nursing banter And the offbeat beeping of cardiac monitors. Like raging tethered wind his limbs all gust, Symmetrically, and stretch his cloth restraints. At his side, I see no stroke that stirs the calm.

Between tears his sister walks me through The gallery, shows me what I failed to see. Crippled at nineteen by a stroke of practicality He became a painter, the unromantic kind, His canvas relegated to trims and vinyl sidings. His next stroke stuttered through middle age, A lacune of apathy large enough for him to Crawl inside and too deep for her to reach him. Tonight, blood thick with alcohol, pills in hand, A stroke of misplaced clarity turns malignant.

His death is dictated between seizures and Sore throats. What is not transcribed is that He passed restlessly, his chest compressed like The shoreline beaten by the rising tide, until The storm cleared and the sky was only grey. 


\section{Neurology}

\section{The common stroke}

Adrian Budhram

Neurology 2017;88;e167

DOI 10.1212/WNL.0000000000003863

\section{This information is current as of April 24, 2017}

\section{Updated Information \&} Services

\section{Subspecialty Collections}

Permissions \& Licensing

\section{Reprints}

including high resolution figures, can be found at: http://n.neurology.org/content/88/17/e167.full

This article, along with others on similar topics, appears in the following collection(s):

All Cerebrovascular disease/Stroke

http://n.neurology.org/cgi/collection/all_cerebrovascular_disease_strok $\mathrm{e}$

All Clinical Neurology

http://n.neurology.org/cgi/collection/all_clinical_neurology

All Psychiatric disorders

http://n.neurology.org/cgi/collection/all_psychiatric_disorders

Information about reproducing this article in parts (figures,tables) or in its entirety can be found online at:

http://www.neurology.org/about/about_the_journal\#permissions

Information about ordering reprints can be found online:

http://n.neurology.org/subscribers/advertise

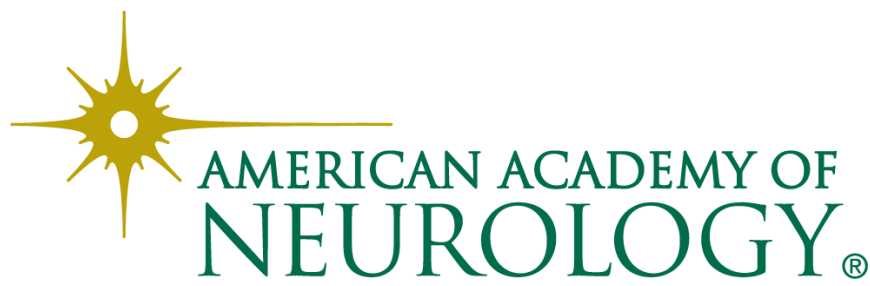

